\title{
Solubility and Activity of Oxygen in Pb-Bi Melts
}

\author{
A. Kishimoto ${ }^{1, * 1}$, A. Wada ${ }^{1, * 2}$, T. Michimoto ${ }^{1, * 3}$, T. Furukawa ${ }^{2}$, K. Aoto $^{2}$ and T. Oishi ${ }^{1}$ \\ ${ }^{1}$ Faculty of Engineering, Kansai University, Suita 564-8680, Japan \\ ${ }^{2}$ Advanced Material Technology Group, Japan Atomic Energy Agency, O-arai 311-1393, Japan
}

In order to obtain the solubility and activity of oxygen in $\mathrm{Pb}-\mathrm{Bi}$ melts, the research for oxygen analysis and oxygen partial pressure measurement in a lead-bismuth eutectic alloy (LBE) was performed. The analytical condition of oxygen in low melting metals by an inert gas fusion-infrared absorption method was established using $\mathrm{Pb}$ or Bi equilibrated with its corresponding oxide at $973 \mathrm{~K}$ as a standard sample for the oxygen analysis. After establishing the analytical condition, oxygen analysis in liquid LBE in equilibrium with solid $\mathrm{PbO}$ at various temperatures was done. The temperature dependence of oxygen solubility in liquid LBE was expressed by the following equation,

$$
\log \left(C_{O} / \text { mass ppm }\right)=-4.74 \times 10^{3} / T+7.06( \pm 0.03) \quad(878 \leqq T / \mathrm{K} \leqq 1073)
$$

Oxygen partial pressure in $\mathrm{LBE}-\left(\mathrm{PbO}\right.$ and/or $\left.\mathrm{PbO}+\mathrm{Bi}_{2} \mathrm{O}_{3}\right)$ equilibrium was measured using an oxygen sensor of a zirconia solid electrolyte $\left(\mathrm{ZrO}_{2}-\mathrm{Y}_{2} \mathrm{O}_{3}\right)$, and obtained as a function of temperature as

$$
\begin{array}{ll}
\log \left(p_{O 2} / P^{\circ}\right)=10.96-2.259 \times 10^{4} / T & (720 \leqq T / \mathrm{K} \leqq 1098) \\
\log \left(p_{O 2} / P^{\circ}\right)=2.49-1.330 \times 10^{4} / T & (1098 \leqq T / \mathrm{K} \leqq 1252)
\end{array}
$$

From the results, the oxygen potential in LBE at the oxygen unsaturated region was estimated as,

$$
R T \ln \left(p_{O 2} / P^{\circ}\right) /(\mathrm{J} / \mathrm{mol})=-58.59 \mathrm{~T}-2.510 \times 10^{5}+38.29 \mathrm{~T} \log \left(C_{O} / \mathrm{mass} \mathrm{ppm}\right)
$$

The activity coefficient of oxygen in liquid LBE obtained using Blander's oxygen dissolution model was compared with these experimental data and those of other investigators.

(Received June 22, 2005; Accepted October 23, 2005; Published January 15, 2006)

Keywords: solubility of oxygen, lead-bismuth, nuclear coolant, oxygen analysis, oxygen partial pressure, activity coefficient, solution model

\section{Introduction}

In recent years, the development of a candidate coolant to take the place of sodium has been focused on in order to improve the safety of nuclear reactors.

The boiling point of LBE is higher and its reactivity with water and air is lower than those of sodium. However, if LBE is used as a coolant, the problem of the pipe corrosion, which originates in the dissolution of the metal into LBE, occurs. According to the IPPE report, ${ }^{1)}$ it may be possible to prevent this corrosion by controlling the oxygen concentration in LBE and forming an oxide protection film on the inner wall of the cooling pipe. To do this, it is necessary to construct a potential diagram of the LBE-oxygen system.

In this study, the solubility of oxygen in LBE in equilibrium with $\mathrm{PbO}$ was obtained by a quenching and analyzing method, and then the equilibrium oxygen partial pressure in $\mathrm{LBE}-\mathrm{PbO}$ equilibrium was measured using an oxygen sensor of zirconia solid electrolyte $\left(\mathrm{ZrO}_{2}+\mathrm{Y}_{2} \mathrm{O}_{3}\right)$. From the results, an oxygen potential and temperature diagram in liquid LBE at the oxygen unsaturated region was estimated.

\section{Experimental}

\subsection{Materials}

A lead sheet of 99.99 mass\% and bismuth grains of

\footnotetext{
${ }^{* 1}$ Graduate Student, Kansai University. Present address: Kobe Steel Ltd Shinko Building, Kobe 651-8585, Japan

${ }^{* 2}$ Graduate Student, Kansai University. Present address: Daido Steel Co., Ltd., Nagoya, 460-8581, Japan

${ }^{* 3}$ Graduate Student, Kansai University. Present address: Osaka Namarisuzu Seirensho Co., Ltd., Osaka, Japan
}

99.99 mass\% pure, both from Mitsubishi Metal. Co., were used. $\mathrm{PbO}, \mathrm{Bi}_{2} \mathrm{O}_{3}$, copper powder and copper(II) oxide powder were all guaranteed reagent grade supplied by Wako Pure Chemical Ind. Ltd.

\subsection{Quenching method}

To prepare a sample of uniform oxygen concentration in the metal, three melting methods were tried using $25 \mathrm{~g}$ of LBE.

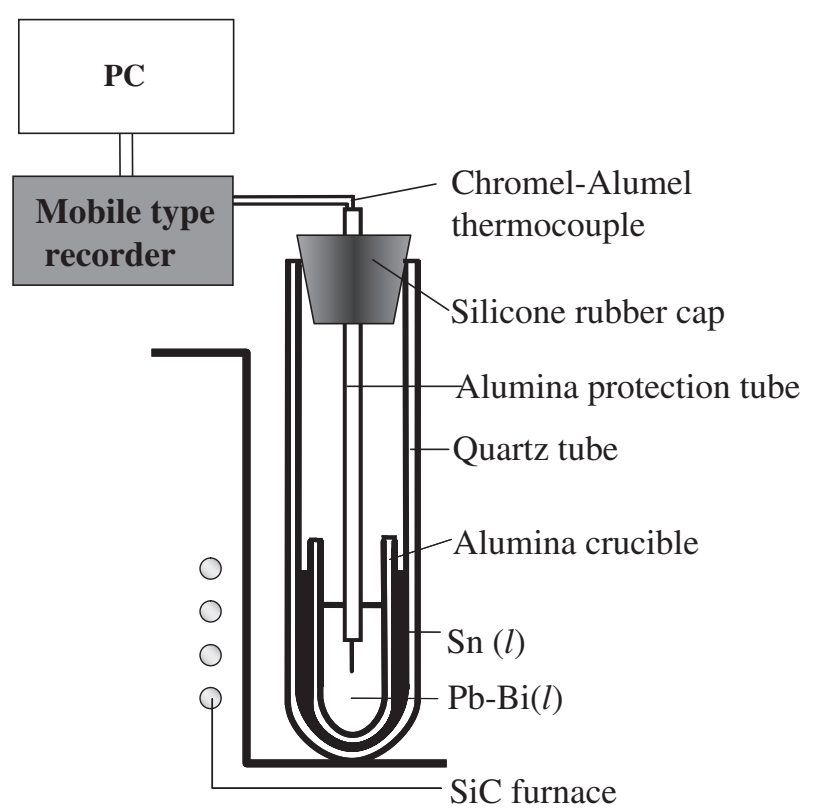

Fig. 1 Schematic apparatus to check the cooling rate of the $\mathrm{Pb}-\mathrm{Bi}$ eutectic alloy (LBE). 


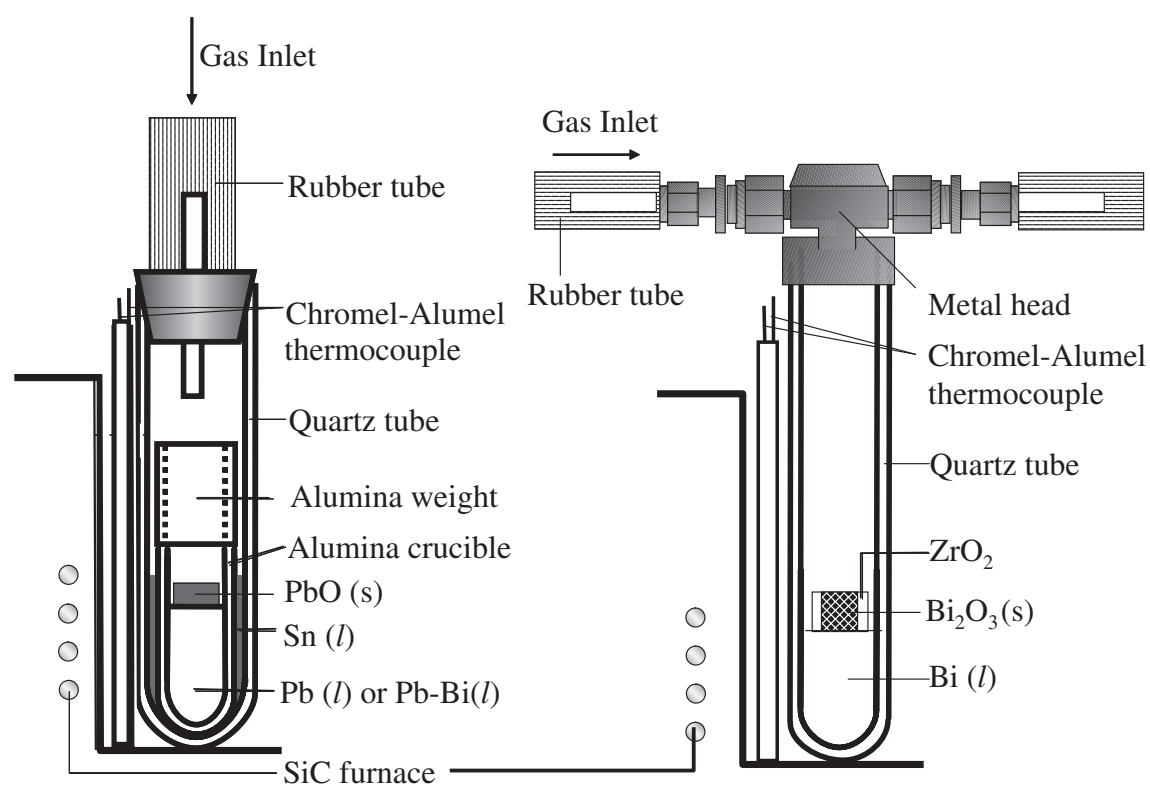

Fig. 2 Schematic apparatus to prepare samples for oxygen analysis.

(1) LBE was melted directly in one closed end silica glass tube (22 $\mathrm{mm}$ OD, $100 \mathrm{~mm} \mathrm{~L}$ ).

(2) LBE was melted in an alumina crucible (15 mm OD, $12 \mathrm{~mm}$ ID and $100 \mathrm{~mm} \mathrm{~L}$ ) placed in a silica glass tube.

(3) LBE was melted in an alumina crucible placed in a silica glass tube with tin between the alumina and the silica glass to accelerate the cooling rate as shown in Fig. 1.

After melting, the silica glass tube was quenched in water. The sample temperature of the cooling process was measured continuously by a thermocouple dipped in the metal and recorded by a mobile type recorder (Keyence NR1000).

\subsection{Oxygen analysis}

The analytical condition of oxygen in low melting metals, using the inert gas fusion method, was established using $\mathrm{Pb}$ or Bi equilibrated with its corresponding oxide at $973 \mathrm{~K}$ as a standard sample for oxygen analysis. A schematic diagram of preparing sample for oxygen analysis is shown in Fig. 2. About $25 \mathrm{~g}$ of lead in contact with $1.5 \mathrm{~g}$ of $\mathrm{PbO}$ pellet was held in an alumina crucible placed in a silica glass tube at $973 \mathrm{~K}$ and $25 \mathrm{~g}$ of bismuth in contact with a $\mathrm{Bi}_{2} \mathrm{O}_{3}$ pellet of $1.5 \mathrm{~g}$ was held directly in the one closed end of a silica glass tube. $\mathrm{Pb}$ was held at $973 \mathrm{~K}$ for $54 \mathrm{ks}$ and $\mathrm{Bi}$ for $36 \mathrm{ks}$ at the same temperature. The holding times, 54 and $36 \mathrm{ks}$, were decided from the result between holding time and oxygen content in liquid LBE in equilibrium with solid $\mathrm{PbO}$, as shown in Fig. 3. The silica glass tube was quenched in water. Each metal ingot was cut into pieces of about $0.2-0.8 \mathrm{~g}$. Just before the oxygen analysis, the sample was washed with nitric acid $(1+4)$ for $\mathrm{Pb}$ and hydrochloric acid $(1+3)$ for $\mathrm{Bi}$, dipped in ethanol, then acetone, and dried.

All samples from the present experiment were analyzed by inert gas fusion and infrared absorbing methods (Horiba Co. Ltd., type EMGA620W).

A tin bath (mol fraction: 0.6) was used to lower the vapor pressure of $\mathrm{Pb}$ and $\mathrm{Bi}$, and the oxygen extraction temperature of the oxygen analyzer was set to $1873 \mathrm{~K}$.

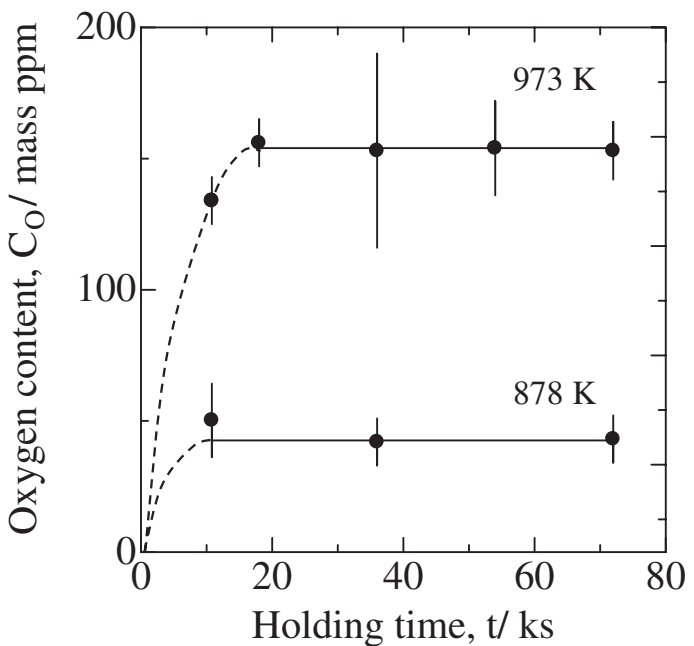

Fig. 3 Change in oxygen contents in liquid LBE with holding time at 878 and $973 \mathrm{~K}$.

\subsection{Oxygen partial pressure measurements}

Galvanic cells used in this study can be represented as follows:

$$
\begin{aligned}
& \text { Pt-LaCrO }{ }_{3}|\mathrm{~Pb}, \mathrm{PbO}| \mathrm{O}^{=}\left|\mathrm{Cu}, \mathrm{Cu}_{2} \mathrm{O}\right| \mathrm{Pt} \\
& \text { Pt-Ir }\left|\mathrm{Bi}, \mathrm{Bi}_{2} \mathrm{O}_{3}\right| \mathrm{O}^{=}\left|\mathrm{Cu}, \mathrm{Cu}_{2} \mathrm{O}\right| \mathrm{Pt} \\
& \text { Pt-LaCrO }{ }_{3} \mid \mathrm{LBE},(\mathrm{PbO} \text { or } \mathrm{PbO} \\
& \left.\quad+\mathrm{Bi}_{2} \mathrm{O}_{3}\right)\left|\mathrm{O}^{=}\right| \mathrm{Cu}, \mathrm{Cu}_{2} \mathrm{O} \mid \mathrm{Pt}
\end{aligned}
$$

A schematic diagram of the cell arrangement is shown in Fig. 4. About $60 \mathrm{~g} \mathrm{~Pb}$ or $\mathrm{Bi}$ with $3 \mathrm{~g}$ of $\mathrm{PbO}$ or $\mathrm{Bi}_{2} \mathrm{O}_{3}$, or about $100 \mathrm{~g}$ of LBE with $6 \mathrm{~g}$ of $\mathrm{PbO}$ was held in an alumina crucible (40 mm OD, $35 \mathrm{~mm}$ ID and $100 \mathrm{~mm} \mathrm{H}$ ) at a constant temperature zone in a mullite reaction tube $(70 \mathrm{~mm}$ OD) closed at one end. In the temperature region where $\mathrm{PbO}$ melted, $\mathrm{ZrO}_{2}+\mathrm{MgO}$ crucible instead of alumina was used. The cell, consisting of a $\mathrm{ZrO}_{2}-\mathrm{Y}_{2} \mathrm{O}_{3}(8 \mathrm{~mm}$ OD, $6 \mathrm{~mm}$ ID and $80 \mathrm{~mm} \mathrm{~L}$ ) solid electrolyte tube, contained a mixture of 


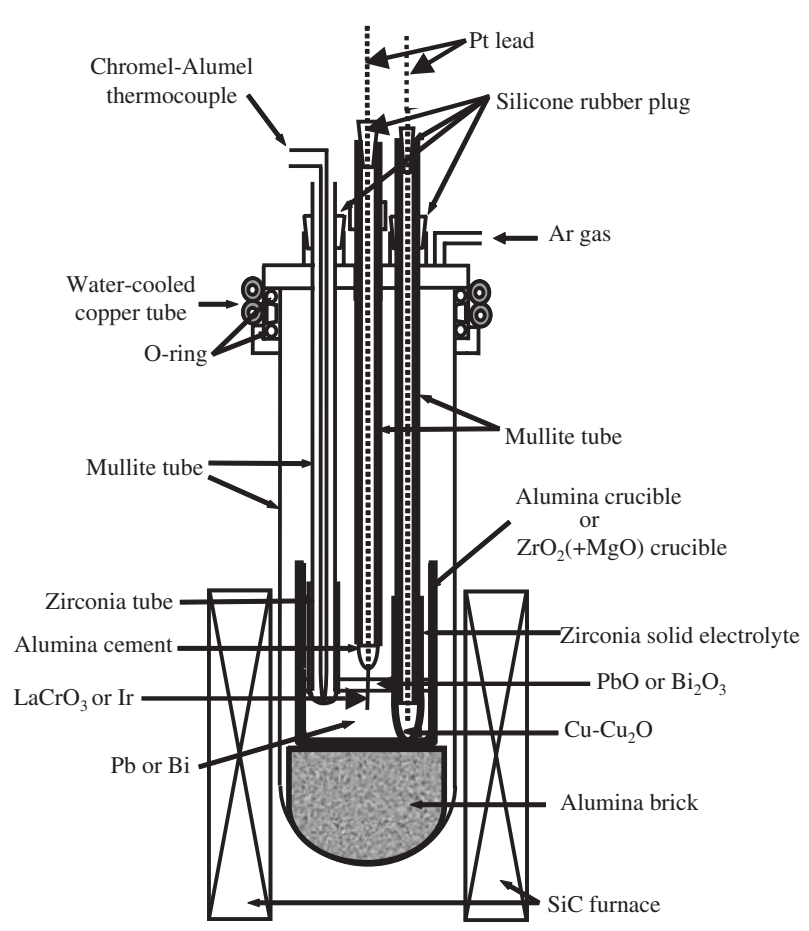

Fig. 4 Schematic arrangement of the cell for EMF measurements.

$\mathrm{Cu}$ and $\mathrm{CuO}$ as a reference electrode. At the experimental temperature, $\mathrm{Cu}$ reacts with $\mathrm{CuO}$, changing to $\mathrm{Cu}+\mathrm{Cu}_{2} \mathrm{O}$ equilibrium. The spiral end of a platinum lead wire was pushed into the reference electrode using an alumina protection tube for the platinum lead, thus good contact being obtained between the reference electrode and the electrolyte.

Two kinds of electrical lead dipped in the melt were used for the melt. $\mathrm{LaCrO}_{3}$ rod ( $2 \mathrm{~mm}$ dia. and $10 \mathrm{~mm}$ long) was used as an electrical contact for cells [I] and [III], and Ir wire $\left(0.5 \mathrm{~mm}\right.$ dia. and $10 \mathrm{~mm}$ long) was for cell [II]. The $\mathrm{LaCrO}_{3}$ rod was placed at the end of the alumina protection tube, electrical contact being made via a platinum lead wound round one end and iridium was spot welded at the tip of the $\mathrm{Pt}$ wire. Both contact parts were covered by alumina cement to prevent the contact of Pt lead with the melt, as shown in Fig. 4.

The upper end of the mullite reaction tube was sealed with a water-cooled stainless cap provided with openings for evacuation and protection tubes for the lead wire of the cell and a thermocouple.

A silicon carbide resistance furnace was used, and its temperature was controlled within $\pm 1 \mathrm{~K}$ using a PID controller.

After the cell was assembled, the reaction tube was evacuated and heated slowly to about $500 \mathrm{~K}$ to ensure gas tightness and dehydration. Ar gas was introduced into the reaction tube and then heated to the temperature for emf measurement under a stream of Ar.

\section{Results and Discussion}

\subsection{Cooling rate}

Figure 5 shows a comparison of the cooling rate among the

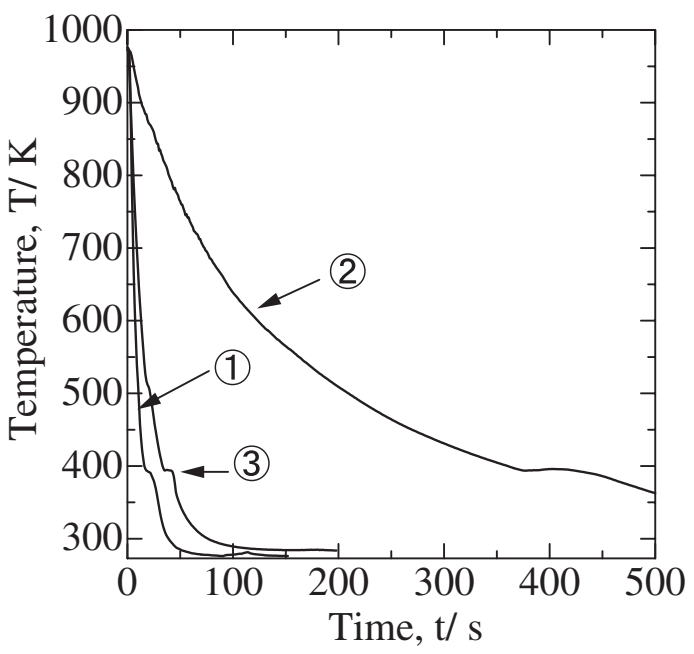

Fig. 5 Comparison of cooling rate among methods (1), (2) and (3).

three different melting methods, (1), (2) and (3). As is clear from the figure, it took $15 \mathrm{~s}$ from 1000 to $400 \mathrm{~K}$ for method (1), and $40 \mathrm{~s}$ for method (3).

According to these results, method (1) was adopted for $\mathrm{Bi}$, and method (3) for $\mathrm{Pb}$ and $\mathrm{LBE}$ to avoid reaction between $\mathrm{PbO}$ and $\mathrm{SiO}_{2}$.

\subsection{Solubility of oxygen in $\mathrm{Pb}, \mathrm{Bi}$ and $\mathrm{LBE}$}

Table 1 shows oxygen concentrations in liquid $\mathrm{Pb}$ and $\mathrm{Bi}$ equilibrated with the respective oxide at $973 \mathrm{~K}$ with the results of other investigators. ${ }^{2-9)}$ Oxygen concentrations in $\mathrm{Pb}$ and $\mathrm{Bi}$ at $973 \mathrm{~K}$ in this study agree well with those of other investigators, although the agreement among the references for $\mathrm{Bi}$ is not good.

From this result, the analytical condition of oxygen using the inert gas fusion-infrared absorption method was found to be suitable for low melting metals.

Figure 6 demonstrates the XRD pattern of $\mathrm{PbO}$ equilibrated with $\mathrm{LBE}$ at 873, 923, 973, 1023 and $1073 \mathrm{~K}$ for $36 \mathrm{ks}$. Only $\mathrm{PbO}$ (yellow + red) was identified; it seemed that the yellow $\mathrm{PbO}$ was generated during cooling. Furthermore, ICP analysis proved that the $\mathrm{Bi}$ content in $\mathrm{PbO}$ was $0.01-$ $0.2 \mathrm{~mol} \%$. From this fact, the oxide equilibrated with LBE was determined to be a solid solution of $\mathrm{PbO}$ below $1098 \mathrm{~K}$, with a very small amount of $\mathrm{Bi}_{2} \mathrm{O}_{3}$.

The logarithms of oxygen concentration in liquid LBE equilibrated with $\mathrm{PbO}$ at 878, 973, 1023 and $1073 \mathrm{~K}$ against the reciprocal of absolute temperature are plotted in Fig. 7 together with the data of Gromov et al. ${ }^{1)}$ Their oxygen solubilities show fairly low compared with our data. The straight line of $\log (\mathrm{Co} / \mathrm{mass} \mathrm{ppm})$ against $1 / \mathrm{T}$ in this study can be expressed by eq. (1).

$$
\begin{aligned}
& \log \left(C_{O} / \text { mass ppm }\right)=-4.74 \times 10^{3} / T+7.06( \pm 0.03) \\
&(878 \leqq T / \mathrm{K} \leqq 1073)
\end{aligned}
$$

\subsection{Oxygen partial pressures in $\mathrm{Pb} / \mathrm{PbO}, \mathrm{Bi} / \mathrm{Bi}_{2} \mathrm{O}_{3}$ and $\mathrm{LBE} /\left(\mathrm{PbO}\right.$ and/or $\left.\mathrm{PbO}+\mathrm{Bi}_{2} \mathrm{O}_{3}\right)$ equilibria}

Emf measurements were carried out using cells [I], [II] and [III], respectively. A steady emf was obtained several hours after reaching the desired temperature. When the 
Table 1 Oxygen solubility limit in $\mathrm{Pb}$ and $\mathrm{Bi}$.

\begin{tabular}{|c|c|c|c|c|c|}
\hline & \multicolumn{2}{|c|}{$\begin{array}{c}\log (\mathrm{Co} / \text { mass ppm }) \\
=\mathrm{A} / T+\mathrm{B}\end{array}$} & \multirow{2}{*}{$\begin{array}{c}\text { Co/mass ppm } \\
T / K=973\end{array}$} & \multirow{2}{*}{$\begin{array}{l}\text { Temp. } \\
(K)\end{array}$} & \multirow[t]{2}{*}{ References } \\
\hline & A & B & & & \\
\hline \multirow[t]{7}{*}{$\mathrm{Pb}$} & -5201 & 7.34 & 98.8 & $601-1073$ & Otsuka and Kozuka²) \\
\hline & -5240 & 7.44 & 113 & $600-1153$ & Alcock and Belford ${ }^{3)}$ \\
\hline & -5000 & 7.20 & 115 & $673-973$ & Gromov $^{1)}$ \\
\hline & -5443 & 7.60 & 101 & - & Charle and Osterwald ${ }^{4)}$ \\
\hline & -5062 & 7.23 & 107 & $773-1773$ & Richardson and Webb ${ }^{5)}$ \\
\hline & -4884 & 7.03 & 102 & - & Risold, Nagata, and Suzuki ${ }^{6}$ \\
\hline & - & - & 91 & 973 & This study \\
\hline \multirow[t]{4}{*}{$\mathrm{Bi}$} & -4820 & 7.26 & 202 & $545-979$ & Otsuka and Kozuka ${ }^{2)}$ \\
\hline & -4660 & 7.02 & 170 & - & $\begin{array}{l}\text { Risold, Hallstedt and } \\
\text { Gauckler }{ }^{7)}\end{array}$ \\
\hline & -3400 & 5.48 & 96.8 & $673-1023$ & Griffith and Mallett ${ }^{8)}$ \\
\hline & - & - & 178 & 973 & This study \\
\hline
\end{tabular}

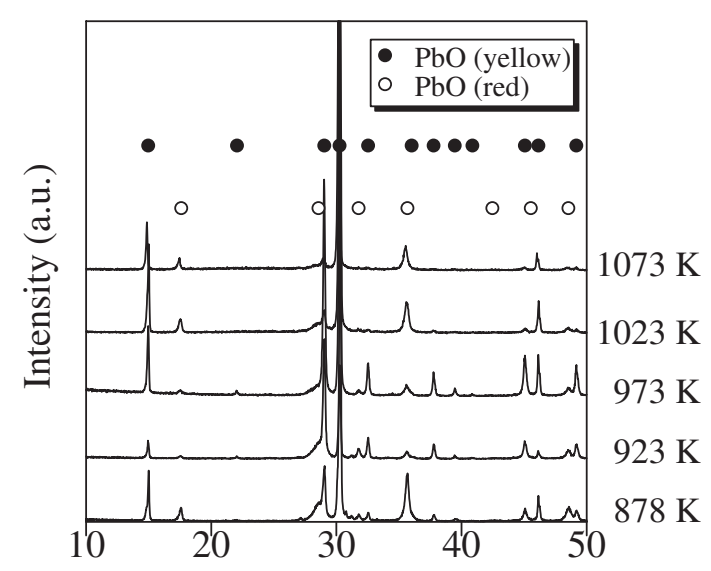

Diffraction angle, $2 \theta / \mathrm{deg}$.

Fig. 6 XRD patterns of the oxide equilibrated with LBE.

Temperature, $\mathrm{T} / \mathrm{K}$

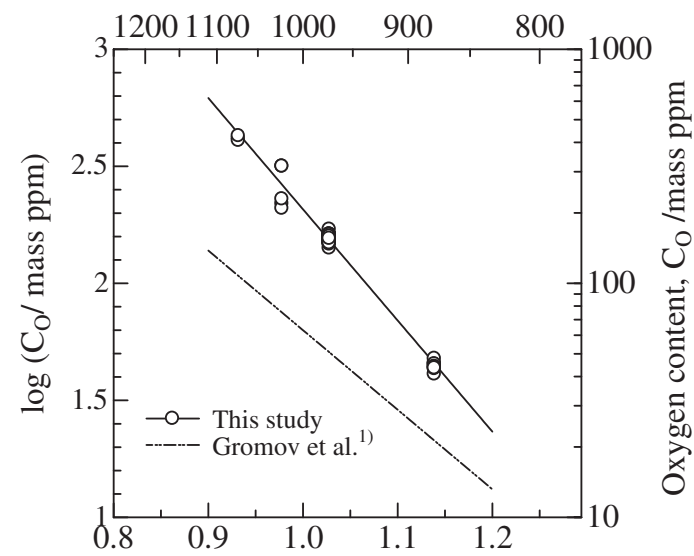

Reciprocal temp., $\left((1 / \mathrm{T}) \cdot 10^{3}\right) / \mathrm{K}^{-1}$

Fig. 7 Relationship between oxygen content in LBE and temperature.

temperature was changed, a new steady emf was obtained after $10.8 \mathrm{ks}$.

Figure 8 shows the temperature dependencies of emf values for cells [I], [II] and [III]. The break point in the emf of
Temperature, $\mathrm{t} /{ }^{\circ} \mathrm{C}$

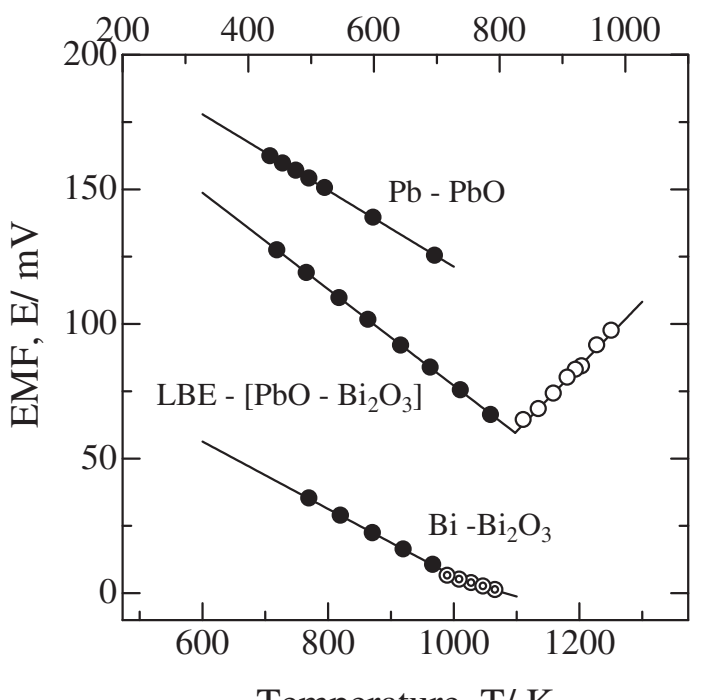

Fig. 8 EMF of cells (I), (II), and (III).

cell [II] corresponds to the transformation of solid $\mathrm{Bi}_{2} \mathrm{O}_{3}$, and that for cell [III] to the melting of $\mathrm{PbO}$ and making $\mathrm{PbO}+$ $\mathrm{Bi}_{2} \mathrm{O}_{3}$ melt.

Least square linear regression analyses gave eqs. (2) to (4) for cells [I], [II] and [III], respectively.

$$
\begin{array}{cc}
E / \mathrm{mV}=262.8-0.1416 T / K( \pm 0.21) \\
(709 \leqq T / \mathrm{K} \leqq 970) \\
E / \mathrm{mV}=131.4-0.1251 T / K( \pm 0.12) \\
(771 \leqq T / \mathrm{K} \leqq 1012) \\
=74.31-0.0687 T / K( \pm 0.06) \\
(1012 \leqq T / \mathrm{K} \leqq 1067) \\
E / \mathrm{mV}=256.3-0.1792 T / K( \pm 0.18) \\
(720 \leqq T / \mathrm{K} \leqq 1098) \\
=-204.5+0.2406 T / K( \pm 0.86) \\
(1098 \leqq T / \mathrm{K} \leqq 1252)
\end{array}
$$


The standard Gibbs energy of formations of $\mathrm{PbO}$ and $\mathrm{Bi}_{2} \mathrm{O}_{3}$ can be obtained by combining the Gibbs energy of formation of $\mathrm{Cu}_{2} \mathrm{O}$ according to Charette and Flengas. ${ }^{10)}$

$$
\begin{aligned}
& \Delta G_{f}^{\circ}(\mathrm{PbO}) / \mathrm{kJ} \cdot \mathrm{mol}^{-1}=- 217.5+0.0986 T \\
&(709 \leqq T / \mathrm{K} \leqq 970) \\
& \Delta G_{f}^{\circ}\left(\mathrm{Bi}_{2} \mathrm{O}_{3}\right) / \mathrm{kJ} \cdot \mathrm{mol}^{-1}=-576.5+0.2863 T \\
&(771 \leqq T / \mathrm{K} \leqq 1012) \\
&=-543.4+0.2537 T \\
&(1012 \leqq T / \mathrm{K} \leqq 1067)
\end{aligned}
$$

The $\Delta G_{f}^{\circ}(\mathrm{PbO})$ and $\Delta G_{f}^{\circ}\left(\mathrm{Bi}_{2} \mathrm{O}_{3}\right)$ of this study agreed very well with those of other investigators., ${ }^{3,9-16)}$

Equations (8) and (9) show the relation between logarithms of partial pressure of oxygen and reciprocal temperature for cell [III].

$$
\begin{gathered}
\log \left(p_{O 2} / P^{\circ}\right)=11.06-2.259 \times 10^{4} / T \\
(720 \leqq T / \mathrm{K} \leqq 1098) \\
\log \left(p_{O 2} / P^{\circ}\right)=2.60-1.330 \times 10^{4} / T \\
(1098 \leqq T / \mathrm{K} \leqq 1252)
\end{gathered}
$$

where $P^{\circ}$ is $101325 \mathrm{~Pa}$.

By combining eqs. (1) and (8) and assuming that Sieverts' law is obeys up to the solubility limit of oxygen in LBE, the oxygen potential at the oxygen unsaturated region was estimated as a function of oxygen concentration and temperature as,

$$
\begin{aligned}
R T & \ln \left(p_{O 2} / P^{\circ}\right) /(\mathrm{J} / \mathrm{mol}) \\
= & -58.59 T-2.510 \times 10^{5} \\
& +38.29 T \log \left(C_{O} / \text { mass ppm }\right)
\end{aligned}
$$

To evaluate the formation of an oxide protection film on

\begin{tabular}{|c|c|c|}
\hline $\begin{array}{l}\text { Oxygen content in LBE, } \\
\mathrm{Co} / \text { mass ppm }\end{array}$ & $\begin{array}{l}\text { Oxides expected to } \\
\text { precipitate }\end{array}$ & $\mathrm{H}_{2} / \mathrm{H}_{2} \mathrm{O}$ ratio \\
\hline $4 \times 10^{-9}$ & None & $\sim 3 \times 10^{5}$ \\
\hline $\begin{array}{l}4 \times 10^{-9} \\
\sim 3 \times 10^{-7}\end{array}$ & $\mathrm{Cr}_{2} \mathrm{O}_{3}$ & $\begin{array}{c}3 \times 10^{5} \\
\sim 3.6 \times 10^{3}\end{array}$ \\
\hline $3 \times 10^{-7}$ & $\mathrm{Cr}_{2} \mathrm{O}_{3}+\mathrm{FeCr}_{2} \mathrm{O}_{4}$ (spinel) & $3.6 \times 10^{3}$ \\
\hline $\begin{array}{c}3 \times 10^{-7} \\
\sim 3 \times 10^{-4}\end{array}$ & $\mathrm{FeCr}_{2} \mathrm{O}_{4}$ (spinel) & $\begin{array}{c}3.6 \times 10^{3} \\
\sim 3.6\end{array}$ \\
\hline $\begin{array}{c}3 \times 10^{-4} \\
\sim 1 \times 10^{-3}\end{array}$ & $\mathrm{FeO}+\mathrm{FeCr}_{2} \mathrm{O}_{4}$ (spinel) & $3.6 \sim 1$ \\
\hline $1 \times 10^{-3} \sim 43$ & $\mathrm{FeCr}_{2} \mathrm{O}_{4}$ (spinel) & $1 \sim 2.9 \times 10^{-5}$ \\
\hline 43 & $\mathrm{PbO}$ precipitation & $2.9 \times 10^{-5}$ \\
\hline
\end{tabular}
the inner wall of the cooling pipe in the lead-bismuth cooled fast reactor, which is basically made of the $\mathrm{Fe}-\mathrm{Cr}$ alloy, the potential diagram of $\mathrm{Pb}-\mathrm{Bi}-\mathrm{O}$ and $\mathrm{Fe}-\mathrm{Cr}-\mathrm{O}$ systems was constructed in Fig. 9. The relation in eq. (10) can be seen in Fig. 9 together with the oxygen potentials of $\mathrm{H}_{2}-\mathrm{H}_{2} \mathrm{O}, \mathrm{Fe}-$ $\mathrm{FeO}, \mathrm{FeO}-\mathrm{Fe}_{3} \mathrm{O}_{4}, \mathrm{Fe}-\mathrm{FeCr}_{2} \mathrm{O}_{4}-\mathrm{Cr}_{2} \mathrm{O}_{3}$ and $\mathrm{Cr}-\mathrm{Cr}_{2} \mathrm{O}_{3}$ equilibria, when considering the equilibrium between $\mathrm{LBE}$ and

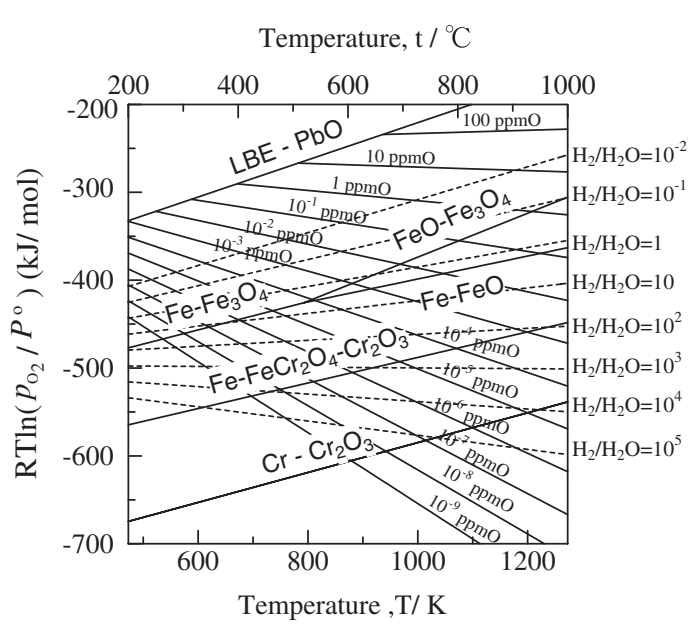

Fig. 9 Potential diagram of $\mathrm{Pb}-\mathrm{Bi}-\mathrm{O}$ and $\mathrm{Fe}-\mathrm{Cr}-\mathrm{O}$ systems.
Table 2 Relationship between oxygen contents in LBE and oxides expected to precipitate on the surface of the $\mathrm{Fe}-10$ mass\% $\mathrm{Cr}$ alloy at $873 \mathrm{~K}$.

$\mathrm{Fe}-\mathrm{Cr}$ alloy containing about 10 mass $\%$ chromium. The oxygen potential of $\mathrm{Fe}-\mathrm{FeCr}_{2} \mathrm{O}_{4}-\mathrm{Cr}_{2} \mathrm{O}_{3}$ equilibrium was obtained by extrapolating the data of Jacob et al. ${ }^{17)}$ down to the temperature region in Fig. 9.

The relation between the oxygen contents in LBE and oxide species, which may be expected to precipitate on the surface of the $\mathrm{Fe}-\mathrm{Cr}$ alloys at a given temperature, can be seen in Fig. 9.

Table 2 shows the relationship between the oxygen contents in LBE and oxides expected to precipitate on the surface of the $\mathrm{Fe}-\mathrm{Cr}$ alloy at $873 \mathrm{~K}$, which is within the operating temperature.

\subsection{Solution model}

Several theories and models have been proposed to describe the compositional variation of the activity coefficient of oxygen, $\gamma_{\mathrm{O}}$, in liquid binary alloys. In 1973, Wagner ${ }^{18)}$ derived an equation for activity coefficient using a chemical approach. The basic assumptions underlying this model are that the solvent atoms exhibit ideal solution behavior and the dissolved oxygen atoms occupy quasiinterstitial sites. In 1981, Blander ${ }^{19)}$ described the dissolution of a solute atom in a binary solvent in terms of four types of atomic interactions. By applying Blander's model to the system $\mathrm{Pb}-\mathrm{Bi}-\mathrm{O}$, eq. (11) may be derived for $\gamma_{\mathrm{O}}$.

$$
\begin{aligned}
& \gamma_{\mathrm{O}}=\left\{\sum_{i=0}^{Z} \frac{Z !}{i !(Z-i) !}\left(\frac{x_{\mathrm{Bi}} \gamma_{\mathrm{Bi}}^{t}}{\gamma_{\mathrm{O}(\mathrm{Bi})}^{1 / Z}}\right)^{Z-i}\left(\frac{x_{\mathrm{Pb}} \gamma_{\mathrm{Pb}}^{t}}{\gamma_{\mathrm{O}(\mathrm{Pb})}^{1 / Z}}\right)^{i} \exp \left[-\frac{g_{i}^{E}}{R T}\right]\right\}^{-1} \\
& g_{i}^{E}=i(Z-i) h_{b} / 2
\end{aligned}
$$

Where

$\gamma_{\mathrm{O}}$ : Activity coefficient of oxygen

$T$ : Temperature of the sysytem

$Z$ : Coordination number of dissolved solute atom

$i$ : Number of $\mathrm{B}$ atom in coordination cluster

$Z-i$ : Number of A atom in coordination cluster

$t$ : Geometric parameter

$x_{\mathrm{Bi}}$ : Molar fraction of component $\mathrm{Bi}$

$x_{\mathrm{Pb}}$ : Molar fraction of component $\mathrm{Pb}$

$\gamma_{\mathrm{Bi}}$ : Activity coefficient of $\mathrm{Bi}$ in $\mathrm{Pb}-\mathrm{Bi}$ binary alloy 


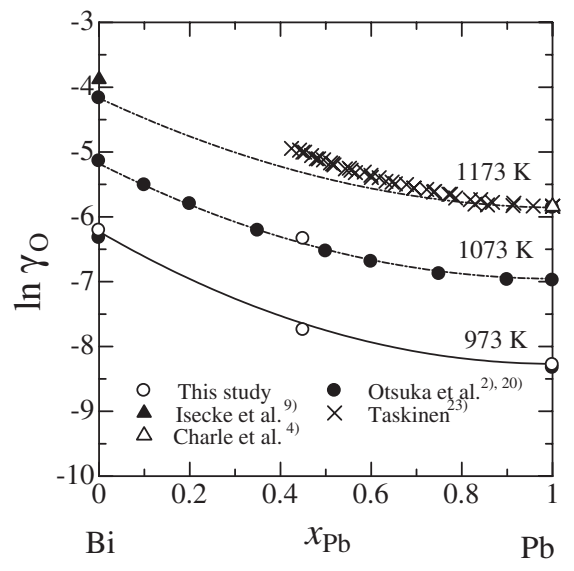

- Calculated using eq.s (11) and (12) and this experimental value. Calculated using eq.s (11) and (12) and Otsuka's experimental value.

Fig. 10 Compositional dependence of the activity coefficient of oxygen, $\gamma_{\mathrm{O}}$, in liquid $\mathrm{Pb}-\mathrm{Bi}$ alloys.

$\gamma_{\mathrm{Pb}}$ : Activity coefficient of $\mathrm{Pb}$ in $\mathrm{Pb}-\mathrm{Bi}$ binary alloy $\gamma_{\mathrm{O}}(\mathrm{Bi})$ : Activity coefficient of oxygen in pure $\mathrm{Bi}$ $\gamma_{\mathrm{O}}(\mathrm{Pb})$ : Activity coefficient of oxygen in pure $\mathrm{Pb}$

$g_{i}^{E}$ : Excess free energy

$h_{b}$ : Enthalpy of solute for coordination cluster

Otsuka et al. ${ }^{20)}$ applied eq. (12) to oxygen in liquid $\mathrm{Pb}-\mathrm{Bi}$ alloys at $1073 \mathrm{~K}$ with $h_{b}=-1.60 \mathrm{~kJ}, t=0.33$ and $Z=6$ and confirmed that the value $\gamma_{\mathrm{O}}(\mathrm{Pb}-\mathrm{Bi})$ obtained by the above model agreed very well with that from their experimental data. Saboungi ${ }^{21)}$ pointed out that the temperature dependence of $h_{b}$ may be ignored. According to his proposal, $\gamma_{\mathrm{O}}(\mathrm{Pb}-$ $\mathrm{Bi})$ at $973 \mathrm{~K}$ in this study was calculated using $h_{b}, t$ and $Z$ to be $-1.60,0.33$ and 6 , respectively, and Moser's experimental $\mathrm{data}^{22)}$ for the activity values of $\mathrm{Pb}-\mathrm{Bi}$ alloys. Figure 10 shows the results together with those of other investigators. ${ }^{4,9,20,23)}$ The curves in the figure, from this study at $973 \mathrm{~K}$ and from Otsuka et al. at 1073 and $1173 \mathrm{~K}$, show $\gamma_{\mathrm{O}}$ obtained using Blander's model. It seems that the agreement between the experimental points and curves from the model calculation is good because the $\mathrm{Pb}-\mathrm{Bi}$ system is regarded to obey the regular solution behavior.

Figure 11 shows the compositional dependence of $p_{O 2}$ for the equilibrium between $\mathrm{Pb}-\mathrm{Bi}$ alloys and $\mathrm{PbO}$ with the experimental data of Sugimoto et al., ${ }^{24)}$ and of Kapoor and Mehrotra. ${ }^{25)}$ The results of this study agreed very well with those of other investigators. Logarithms of $p_{O 2}$ were expressed as follows.

$$
\begin{gathered}
\log \left(p_{O 2} / P^{\circ}\right)=1.70 x_{\mathrm{Pb}}^{2}-4.09 x_{\mathrm{Pb}}-10.66 \\
(973 \mathrm{~K}) \\
\log \left(p_{O 2} / P^{\circ}\right)=1.19 x_{\mathrm{Pb}}^{2}-3.33 x_{\mathrm{Pb}}-8.74
\end{gathered}
$$

$(1073 \mathrm{~K})$

Combining the $p_{\mathrm{O} 2}$ values and $\gamma_{\mathrm{O}}(\mathrm{Pb}-\mathrm{Bi})$ calculated by Blander's coordination cluster theory, a model calculation of composition dependence of solubility limit of oxygen in a $\mathrm{Pb}-\mathrm{Bi}$ melt was performed and is shown in Fig. 12.

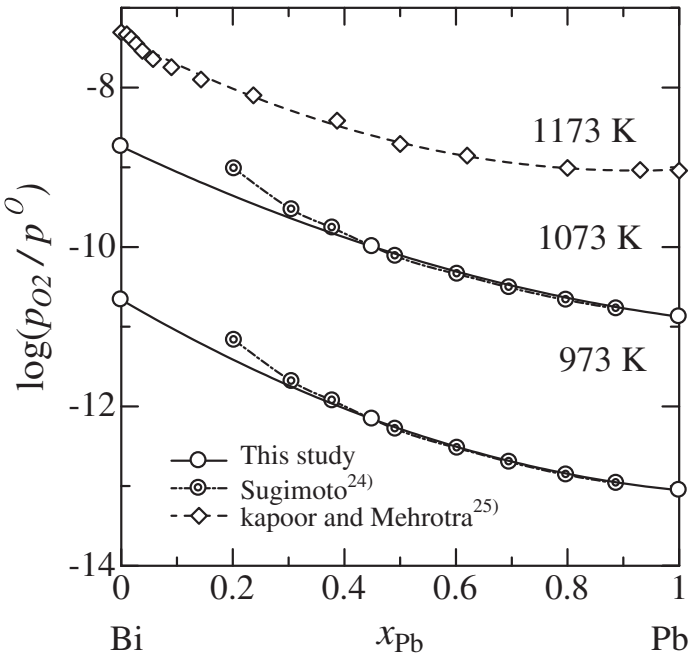

Fig. 11 Compositional dependence of oxygen partial pressure in liquid $\mathrm{Pb}-\mathrm{Bi}$ alloys.

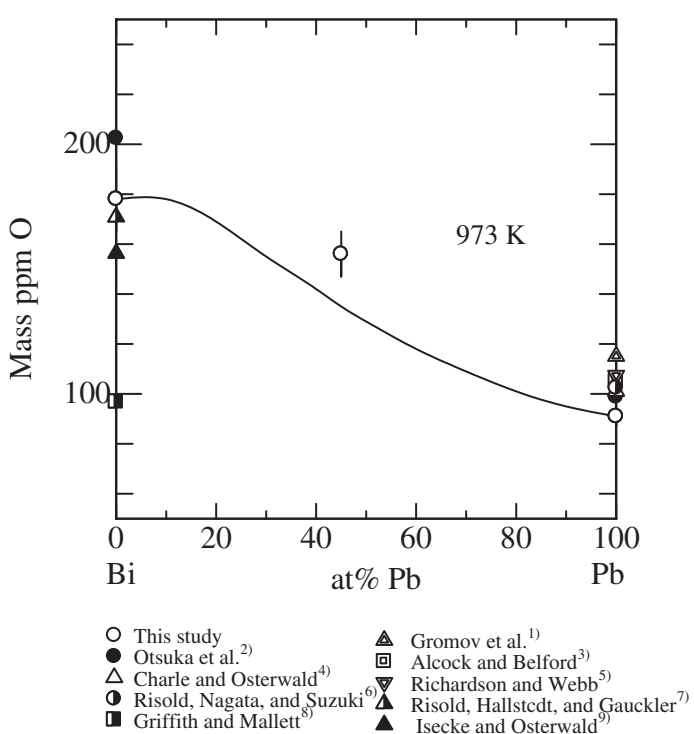

Fig. 12 Calculated and experimental oxygen solubility limits in liquid $\mathrm{Pb}-$ Bi alloys at $973 \mathrm{~K}$.

\section{Summary}

In order to obtain the solubility and activity of oxygen in $\mathrm{Pb}-\mathrm{Bi}$ melts, research for oxygen analysis and oxygen partial pressure measurement in lead-bismuth eutectic alloy (LBE) was performed. The analytical condition of oxygen in low melting metals was established using $\mathrm{Pb}$ or $\mathrm{Bi}$ equilibrated with its corresponding oxide at $973 \mathrm{~K}$ as standard samples.

The temperature dependence of oxygen solubility in liquid LBE was expressed by the following equation,

$$
\begin{aligned}
& \log \left(C_{O} / \text { mass ppm }\right)=-4.74 \times 10^{3} / T+7.06( \pm 0.03) \\
&(878 \leqq T / \mathrm{K} \leqq 1073)
\end{aligned}
$$

Oxygen partial pressure in LBE- $\left(\mathrm{PbO}-\mathrm{Bi}_{2} \mathrm{O}_{3}\right)$ equilibrium was measured using an oxygen sensor of a zirconia solid electrolyte $\left(\mathrm{ZrO}_{2}-\mathrm{Y}_{2} \mathrm{O}_{3}\right)$, and obtained as a function of temperature as 


$$
\begin{aligned}
& \log \left(p_{O 2} / P^{\circ}\right)= 11.06-2.259 \times 10^{4} / T \\
&(720 \leqq T / \mathrm{K} \leqq 1098) \\
& \log \left(p_{O 2} / P^{\circ}\right)=2.60-1.330 \times 10^{4} / T \\
&(1098 \leqq T / \mathrm{K} \leqq 1252)
\end{aligned}
$$

From the results, the oxygen potential in LBE at the oxygen unsaturated region was estimated as,

$$
\begin{aligned}
R T \ln \left(p_{O 2} / P^{\circ}\right) /(\mathrm{J} / \mathrm{mol})= & -58.59 T-2.510 \times 10^{5} \\
& +38.29 T \log \left(C_{O} / \text { mass ppm }\right) .
\end{aligned}
$$

Oxide species expected to precipitate on the $\mathrm{Fe}-\mathrm{Cr}$ alloy were discussed when considering the equilibrium between $\mathrm{LBE}$ and $\mathrm{Fe}-\mathrm{Cr}$ alloy from the relationship between oxygen partial pressure and oxygen content in LBE.

Compositional dependencies of the activity coefficient of oxygen, oxygen partial pressure and solubility of oxygen in LBE were calculated and compared with the literature data.

\section{REFERENCES}

1) B. F. Gromov et al:: The Problems of Technology of the Heavy Liquid Metal Coolants (Lead-Bismuth, Lead) (1998).

2) S. Otsuka and Z. Kozuka: Trans. JIM 22 (1981) 558-566.

3) C. B. Alcock and T. N. Belford: Trans. Faraday Soc. 60 (1964) 822835 .

4) H. Charle and J. Osterwald: Z. Phys. Chem. 99 (1976) 199-208.

5) F. D. Richardson and L. E. Webb: Trans. Ins. Min. Metall. 64 (195455) $529-564$

6) D. Risold, J.-I. Nagata and R. O. Suzuki: J. Phase Equilibria 19 (1998)
213-233.

7) D. Risold, D. Hallstedt, L. J. Gauckler, H. L. Lukas and S. G. Fries: J. Phase Equilibria 16 (1995) 223-234.

8) C. B. Griffith and M. W. Mallett: J. Am. Chem. Soc. 75 (1953) 18321834.

9) B. Isecke and J. Osterwald: Z. Phys. Chem. Neue Folge 115 (1979) 1724.

10) G. G. Charette and S. N. Flengas: J. Electrochem. Soc. 115 (1968) 796804.

11) K. T. Jacob and J. H. E. Jefles: Trans. Inst. Min. Metall. 80 (1971) C3241.

12) A. Roine: Outokumpu HSC Chemistry for Windows, Chemical Reaction and Equilibrium Software Extensive Thermochemical Database (2000).

13) O. Knacke, O. Kubaschewski and K. Hesselmann: Thermochemical Properties of Inorganic Substances, 2nd ed. (Springer Verlag, 1991).

14) J. P. Coughlin: Bull. 542, Bureau of Mines, Contributions to the data on theoretical metallurgy (1954) 27.

15) K. Kameda, K. Yamaguchi and T. Kon: J. Japan Inst. Metals 56 (1992) 900-906.

16) R. Ganesan, T. Gnanasekaran and R. S. Srinivasa: J. Chem. Thermodyn. 35 (2003) 1703-1716.

17) K. T. Jacob and C. B. Alcock: Metall. Trans. B 6B (1975) 215-221.

18) C. Wagner: Acta Met. 21 (1973) 1297-1303.

19) M. Blander, M.-L. Saboungi and P. Cerisier: Metall. Trans. B 10B (1979) 613-622.

20) S. Otsuka, Z. Kozuka and Y. Kurose: Metall. Trans. B 15B (1984) 141147.

21) M.-L. Saboungi, P. Cerisier and M. Blander: Metall. Trans. B 13B (1982) 429-437.

22) Z. Moser: Z. Metallk. 64 (1973) 40-46.

23) A. Taskinen: Z. Metallk. 73 (1982) 163-168.

24) E. Sugimoto: Ph. D. thesis, Osaka University, 1983.

25) M. L. Kapoor and G. M. Mehrotra: Trans. Indian. Inst. Met. 32 April (1979) 152-156. 